73 巻 732 号 $(2007-8)$

\title{
タワークレーン用平行リンク型免震装置の開発*
}

\author{
小林 信 之*1, 袴 田和 広*2
}

\section{Parallel Link Type Seismic Isolator for Tower Crane}

\author{
Nobuyuki KOBAYASHI*3 and Kazuhiro HAKAMADA \\ ${ }^{* 3}$ Department of Mechanical Engineering, Aoyama Gakuin University, \\ 5-10-1 Fuchinobe, Sagamihara-shi, Kanagawa, 229-8558 Japan
}

\begin{abstract}
A new type seismic isolator system for the tower crane is presented. The isolator system is composed of two components. One is an isolator for the mast of the crane using a cubic four bar links, springs, dampers and stoppers. The other is the elastic stay, which connects a stay supported type tower crane to the structure under construction. The natural period and the damping coefficient of the tower crane can be turned by adjusting spring constant, damping coefficient of dampers and the stiffness of stays. Numerical simulations for a self-stand tower crane and a stay supported type tower crane with the presented seismic isolator system and these without seismic isolator are carried out. The shaking table exciting test for a self-stand tower crane model with the presented seismic isolator is also carried out. As the results, the simulation results and the experimental results demonstrate that the presented isolator system is effective to decrease seismic inertia force.
\end{abstract}

Key Words : Tower Crane, Seismic Isolation, Seismic Response, Seismic Motion, Base Shear

\section{1. 緒 言}

タワークレーンは建築物等の建設に広く用いられて いるが, 1995 年の阪神・淡路大震災(1,2)や2002 年の台 湾東部地震(3)において破損, 倒壊, 落下寸るなどの地 震被害が報告されている. 従って, 市街地等で作業す るタワークレーンの地震時安全性を向上することはき わめて重要である(4).

図 1 に示すように, タワークレーンには自立する構 造（以下，自立型クレーン）と建築物からステーによ り水平支持される構造 (以下, ステー支持型クレーン) がある. タワークレーンは細いマスト(1)上に質量の 大きな旋回部(3)と起伏するジブ(2)が設置されている構 造であるため, 柔軟な上に重心が高く, かつ, ジブの 起伏角度により振動特性が変化する構造物である.

自立型クレーンは，地震時にその基礎部(4)が震動す ることにより励振されるが, ステー支持型クレーンは, その基礎部からのみならず，ステー(6)を介して建築物 (7からも励振されるので, 特に最上段ステーより上部 の応答が大きくなる．また，タワークレーンの慣性力

* 原稿受付 2007 年 4 月 12 日.

*1 正員, フェロー, 青山学院大学理工学部 (雪 229-8558 相模原 市淵野辺 5-10-1).

$* 2$ 青山学院大学理工学研究科.

E-mail : kobanobu@me.aoyama.ac.jp
が反力として建築物に作用するので，建築物の補剛が 必要になる場合も生じる.

以上のことから, タワークレーンの基本構造を大き く変えることなしに, 地震時の安全性を向上するため には，免震化または制振化が望まれる．タワークレー ンの免震化を行う場合, 転倒モーメントによる引抜力 が大きいこと，および垂直軸周りのねじりモーメント がジブの姿勢により生じることを考慮する必要がある (5).

そこで, 本研究では, コンパクトでシンプルな構造 を特徵とする平行リンク型免震装置と軸方向のみに柔

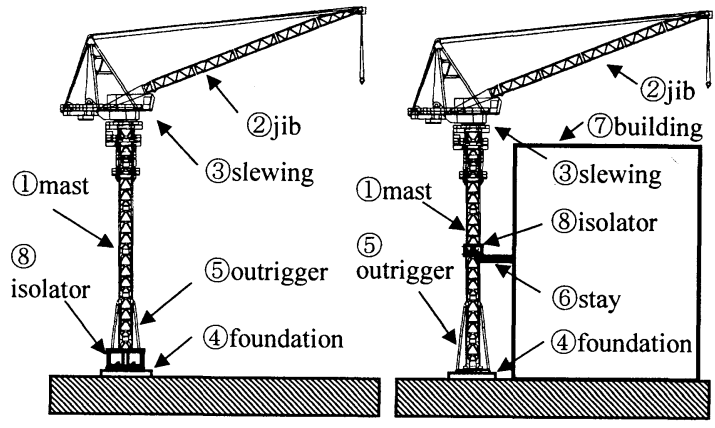

$\begin{array}{ll}\text { (a) Self-stand type crane } & \text { (b) Stay supported type crane }\end{array}$ Fig.1 Typical tower crane 
性を持つ弾性ステーから構成される免震機構を提案す る. そしてタワークレーンの振動モードを考慮した免 震機構の設置位置を提案し，その有効性の基本的な検 討を数値シミュレーションおよび加振実験によって行 った結果を報告する.

\section{2. 免 震 機 構}

本研究で提案するタワークレーンの免震機構は，マ ストの免震装置および免震ステーの 2 つから成る.

自立型クレーンは，図 1(a)に示したようにマスト基 礎部に免震装置(8)を設置することにより固有周期を長 周期化することができ，地震時に大きく振動するマス トとジブの慣性力を低减する，一方，ステー支持型ク レーンは，ステーを介しての構造物からの励振も低減 する必要があるので, 図 1(b)に示したように免震ステ 一(6)と最上段ステー直上に免震装置(8)を設置すること により，マスト上部とジブの慣性力を低减する.

以下に，提案する平行リンク型免震装置と免震ステ 一の構造と動作原理を示す.

$2 \cdot 1$ 平行リンク型免震装置 図 2 に, 本研究で 提案する平行リンク型免震装置の構造を示す．高さ方 向に平行な 2 つの板状受台(9)(10) 4 隅および中間点を, 両端に自在に回転可能な関節を持つ長さ $l$ なる 6 本の リンク111により，それぞれ対応する点に接続して立体 的な平行リンクを構成する. 一方の板状受台中心部に 棒状支柱(12)を垂直に設置し，その棒状支柱と他方の板 状受台端部近傍との間をばねとダンパー113により接続 し，2 つの板状受台間に生じる相対変位と速度に比例 した復元力と減衰力を与える.

本免震装置はトリガー機構を備えており，地震水平 慣性力が所定の值以上になった時に，下部受台(10)と棒 状支柱(12)の間に設けたシャーピンを用いたトリガー機 構が動作して免震装置が作動する，万一，地震慣性力 が想定した值より大きくなり，免震装置の変位が大き くなる場合には，ストッパー機構(15により過大な変形 を防ぐことが可能である.

この平行リンク型免震装置はタワークレーンの下端 または適切な位置に挿入することが可能であり，免震

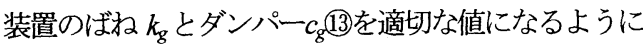
調整することによりタワークレーンの固有周期を変化 させることができ, 免震が可能となる.

免震装置の作動時に，平行リンクが傾くことにより 生じる自重に比例した水平力をばね $k_{g}$ が受け持つ. 自 重 $M$ により不安定にならない条件は $k_{g} \geq M g / l$ である. また，このばねにより免震装置の固有周期も決まるの でここれらの制約から $k \mathrm{~g} を$ を決定できる.
$2 \cdot 2$ 免震ステ一 図 3 に提案寸る免震ステーの 構造を示寸、ステ一部材16を途中で分割し，ばねとダ ンパー17〕直列に挿入する. 両端部にストッパー19が 設けられた軸力部材(18)をガイド(20でステー部材と平行 に固定する.この軸力部材は通常使用時の軸力を負担 すると共に，作動時のステーの面外変形を拘束する役 割もある．軸力部材にトリガー機構を設けることによ り，地震水平慣性力が所定の值以上になった時にトリ ガー機構が動作してステーのばね定数 $k_{s}$ を低下させる.

\section{3. タワークレーンのモデル化}

図4(a)に自立型クレーンの剛体リンクモデルを，(b)

(13)spring and damper

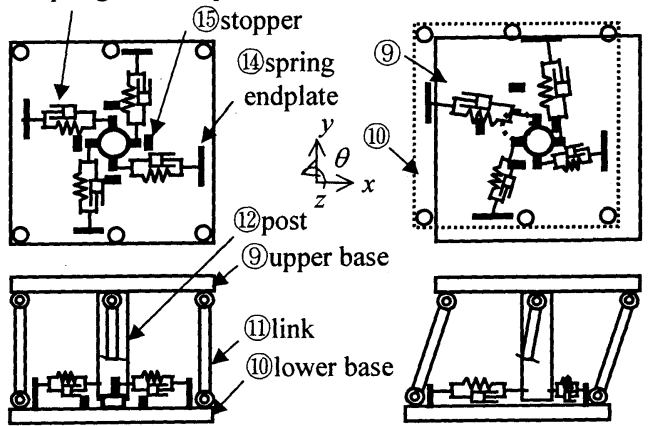

Fig.2 Scheme of cubic parallel link type isolator

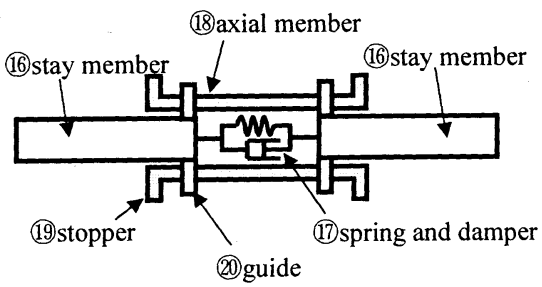

Fig.3 Scheme of isolation stay

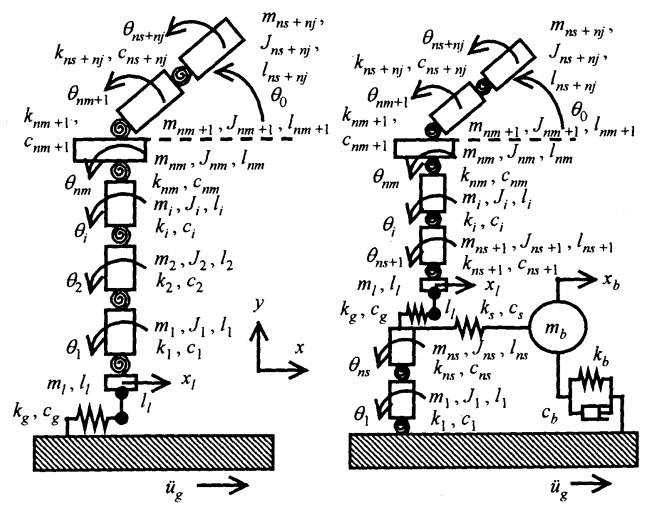

$\begin{array}{ll}\text { (a) Self-stand type crane } & \text { (b) Stay supported type crane }\end{array}$

Fig.4 Tower crane model with presented isolators. 
にタワークレーンがステーを介して建築物と連成した 系の岡体リンクモデルを示す.ここでは免震機構の基 本的特性を明らかにすることを目的にしているので, 図4 に示したジブを含む面内の応答について議論する. タワークレーンを, 旋回部を含むマスト部を $n_{m}$ 個の 剛体，ジブ部を $n_{j}$ 個の剛体に分割し，それぞれの接続 部にマスト部またはジブ部の曲け剛性に相当する回転 ばね $k_{i}$ を設置した，質量 $m_{l}$ ，長さ $l_{l}$ からなる平行リン ク型免震装置は自立型クレーンに関しては基礎部に設 置し，ステー支持型クレーンに関しては最上段ステー 接続部の直上である $n_{s}$ 番目と $n_{s+1}$ 番目の剛体の間に設 置し，その剛性を $k_{g}$, 減衰を $c_{g}$ としてモデル化した. 建築物は質量 $m_{b}$ とせん断岡性を表すばね定数 $k_{b}$, ダ ンパー $c_{b}$ からなる 1 自由度系とする. 建築物とクレー ンとをつなぐステーは水平ばね $k_{s}$, ダンパー $c_{s}$ を用い てモデル化した.

ただし，図中の記号は，以下の通りである.

$m_{i}, J_{i}, l_{i}: i$ 番目剛体の質量, 慣性モ一メント及び長さ

$k_{i}, c_{i}: i$ 番目回転ばねのばね定数及び減衰係数

$\theta_{i}: i$ 番目剛体の絶対角度

$x_{l}, x_{b}:$ 免震装置および建築物の水平変位

タワークレーンモデルのマストおよびジブの重力ば ね効果を含めた運動方程式は式(1)で与えられる.ただ し，一般化座標 $\mathbf{q}$ は，自立型クレーンの場合は $\mathbf{q}_{\text {self; }}$ ステー支持型クレーンの場合は $\mathbf{q}_{\mathrm{s} a x y}$ である.

$$
\begin{aligned}
& \mathbf{M} \ddot{\mathbf{q}}+\mathbf{C} \dot{\mathbf{q}}+\mathbf{K q}+\mathbf{W} \ddot{u}_{g}+\mathbf{G}=\mathbf{0} \\
& \mathbf{q}_{\text {self }}=\left[\begin{array}{llll}
x_{l} & \theta_{1} & \cdots & \theta_{\left(n_{m}+n_{j}\right)}
\end{array}\right]^{\mathrm{T}} \\
& \mathbf{q}_{\text {stay }}=\left[\begin{array}{lllll}
x_{b} & x_{l} & \theta_{1} & \cdots & \theta_{\left(n_{m}+n_{j}\right)}
\end{array}\right]^{\mathrm{T}}
\end{aligned}
$$

ここで，M，C，K はそれぞれ質量，減衰，剛性行列

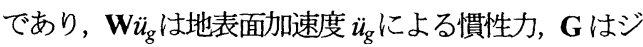
ブの姿勢に依存する重力加速度による慣性力である。

クレーンに作用する地震慣性力の指標としてクレー ン全体の層せん断力係数 $C_{h}$, および，ステ一支持型ク レーンにおけるステー接続部より上部の層せん断力係 数 $C_{h u}$ をそれぞれ以下のように定義する.

$$
\begin{array}{r}
C_{h}=\frac{m_{l} \ddot{x}_{l}+\sum_{i=1}^{n m+n j} m_{i} \ddot{x}_{i}}{\left(m_{l}+\sum_{i=1}^{n m+n j} m_{i}\right) g} \\
C_{h u}=\frac{m_{l} \ddot{x}_{l}+\sum_{i=n s+1}^{n m+n j} m_{i} \ddot{x}_{i}}{\left(m_{l}+\sum_{i=n s+1}^{n m+n j} m_{i}\right) g}
\end{array}
$$

ここで， $\ddot{x}_{i}$ は $i$ 番目剛体の重心位置における絶対水 平加速度である.

\section{4. 実 験}

平行リンク型免震装置の基本的な動特性を調べるた め，自立型クレーンの模型を設計・製作し，加振実験 を行った. マスト部には高さ $1.3 \mathrm{~m}$, 断面 $30 \mathrm{x} 40 \mathrm{~mm}$, 板厚 $2 \mathrm{~mm}$, 質量 $0.9 \mathrm{~kg}$ のアルミ角柱を，旋回部および ジブ部は質量 $3.85 \mathrm{~kg}$ の鋼製ブロックを用いた. 免震装 置は, 平行リンク部に長さ $118 \mathrm{~mm}$, 直径 $10 \mathrm{~mm}$ の丸棒, 上下受台に $156 \mathrm{~mm}$ 角, 板厚 $15 \mathrm{~mm}$ の鋼板を用いた。 図 5 に設計・製作した免震クレーン模型の構成を示す. 式(1)から求まる, 非免震クレーン模型の 1 次固有振 動数は $4.4 \mathrm{~Hz}$ であり, 免震クレーン模型の 1 次固有振 動数は $2.0 \mathrm{~Hz}, 2$ 次固有振動数は $5.9 \mathrm{~Hz}$ であった. 表 2 に示す加振条件により，クレーン模型の一定変位正弦 波スイープ加振実験を行った。

図 6 に振動台加速度に対するマスト頂部加速度の伝 達関数を示すここれらの実験結果から，非免震クレー ン模型の 1 次固有振動数は $4.3 \mathrm{~Hz}$ ，減衰比は $2.0 \%$, 免 震クレーン模型の 1 次固有振動数と減衰比は $2.0 \mathrm{~Hz}$, $12 \%$ であり，2次固有振動数と減衰比は $5.8 \mathrm{~Hz}, 2.0 \%$ となった.

固有振動数は解析結果と良く一致しており，平行リ ンク型免震装置によりクレーン模型の 1 次固有振動数

Table 1 Sweep test condition

\begin{tabular}{|c|c|}
\hline Sweep range & $0.5-8.5$ \\
\hline Sweep rate & $0.05 \mathrm{~Hz} / \mathrm{s}$ \\
\hline Sweep time & $160 \mathrm{~s}$ \\
\hline Exciting amplitude & $0.4 \mathrm{~mm}$ \\
\hline
\end{tabular}

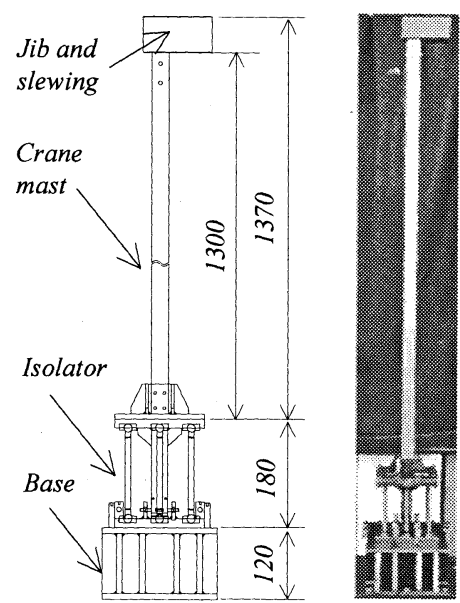

Fig.5 Experimental setup 


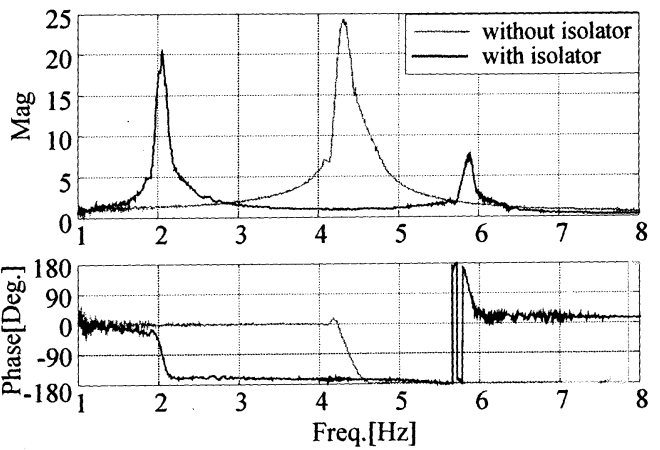

Fig.6 Frequency response of the top of the mast

を低くできることが確認された．また，非免震クレー ン模型の固有振動数である $4.3 \mathrm{~Hz}$ 付近では振幅倍率が 小さくなり, この振動数領域において免震装置の効果 があることを示すことができた.

しかしながら, ジブ直交方向に加振したケースでは， 若干のねじれがみられた.リンクのがた等が原因と考 えられるが，今後検討する必要がある.

\section{5. 実機サイスタタークレーンの地震応答解析}

$5 \cdot 1$ 解析条件 提案寸る免震機構の免震効果を 調べるために，実機サイズの自立支持型クレーンとス テー支持型クレーンについて，以下に示寸条件により 地震応答解析を実施した.

対象とするタワークレーンはマスト高さおよび質量 を $65.5 \mathrm{~m}$ と $76.5 \times 10^{3} \mathrm{~kg}$ ，旋回部の質量を $65 \times 10^{3} \mathrm{~kg}$, ジ ブの質量を $7.4 \times 10^{3} \mathrm{~kg}$ ，長さが $40 \mathrm{~m}$ ，ジブの姿勢角を $\pi / 6 \mathrm{rad}$ とした. 平行リンク型免震装置は高さが $l_{l}=2.0 \mathrm{~m}$, 質量が $m_{l}=3.0 \times 10^{3} \mathrm{~kg}$ とした. タワークレーン本体 1 次 振動モードの減衰比原を $2.5 \%$ になるうにマストと ジブの減衰俰数を定めた. また, 免震装置を取り付け た場合はタワークレーン 1 次振動モードの固有振動数

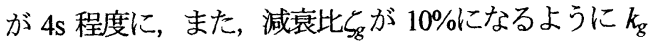
と $c_{g}$ を設定した.

本解析では, クレーンの分割数を $n_{m}=4, n_{F}=2, n_{s}=2$ とした. 地震觉答解析に用いたタワークレーンに関す る主要な仕様を表 2 に, 平行リンク型免震装置に関す る主要な仕様を表 3 に示寸。

ステー支持型クレーンにおいては, 従来型ステーの 軸岡性を $k_{s}=1.0 \times 10^{9} \mathrm{~N} / \mathrm{m}$, 免震ステーの軸岡性を $k_{s}$ $=1.0 \times 10^{6} \mathrm{~N} / \mathrm{m}$ とし, 免震ステーの減衰係数 $c_{s}$ は免震機 構を取り付けたクレーンの 1 次振動モードの減衰比 が 10\%になるように設定した. また，建築物は 22 階 建ての建物を想定し, 高さ $70 \mathrm{~m}$, 質量 $m_{b}=1.4 \times 10^{7} \mathrm{~kg}$, 減衰比 $\zeta_{b}=2.5 \%$ とした. 建築物の影響を調べるために,
Table 2 Specification of tower crane

\begin{tabular}{|c|c|c|c|c|}
\hline$i$ & $\begin{array}{c}m_{i} \\
(\mathrm{~kg})\end{array}$ & $\begin{array}{c}J_{i} \\
\left(\mathrm{kgm}^{2}\right)\end{array}$ & $\begin{array}{c}l_{i} \\
(\mathrm{~m})\end{array}$ & $\begin{array}{c}k_{i} \\
(\mathrm{Nm} / \mathrm{rad})\end{array}$ \\
\hline 1 & $4.00 \times 10^{4}$ & $1.20 \times 10^{7}$ & 30.0 & $3.20 \times 10^{10}$ \\
\hline 2 & $1.25 \times 10^{4}$ & $1.16 \times 10^{6}$ & 11.5 & $6.17 \times 10^{9}$ \\
\hline 3 & $2.40 \times 10^{4}$ & $5.20 \times 10^{6}$ & 24.0 & $6.61 \times 10^{9}$ \\
\hline 4 & $6.50 \times 10^{4}$ & $1.35 \times 10^{5}$ & 2.5 & $1.15 \times 10^{10}$ \\
\hline 5 & $3.70 \times 10^{3}$ & $4.93 \times 10^{5}$ & 20.0 & $3.80 \times 10^{8}$ \\
\hline 6 & $3.70 \times 10^{3}$ & $4.93 \times 10^{5}$ & 20.0 & $6.00 \times 10^{8}$ \\
\hline
\end{tabular}

Table 3 Specification of isolator

\begin{tabular}{|cc|c|c|}
\hline \multicolumn{2}{|c|}{ Symbol } & Self-stand crane & Stay supported crane \\
\hline$m_{l}$ & $\mathrm{~kg}$ & \multicolumn{2}{|c|}{$3.00 \times 10^{3}$} \\
\hline$l_{l}$ & $\mathrm{~m}$ & \multicolumn{2}{|c|}{2.0} \\
\hline$k_{g}$ & $\mathrm{~N} / \mathrm{m}$ & $1.14 \times 10^{6}$ & $7.53 \times 10^{5}$ \\
\hline$c_{g}$ & $\mathrm{Ns} / \mathrm{m}$ & $2.49 \times 10^{5}$ & $2.16 \times 10^{5}$ \\
\hline
\end{tabular}

建築物の岡性 $k_{b}$ をパラメータとして変化させ, 固有周 期 $T_{b}$ を $0.5,1.0,1.5,2.0,3.0,4.0,5.0 \mathrm{~s}$ になるよう にした.

自立型クレーンに関しては，現行のタワークレーン を想定した非免震クレーン(Casel) と基礎部に免震装 置を設置した免震クレーン(Case2)に対して地震応答 解析を行った. 一方，ステー支持型クレーンに関して は, 現行のタワークレーンを想定した非免震クレーン (Case3), マストのみを免震したクレーン(Case4), およ び, マストとステーを免震したクレーン(Case5)に対し て地震応答解析を行った.

地震応答解析は，短周期が卓越するものから長周期 が卓越するものまで幾つかの入力地震波を用いること とし, 1995 年の阪神大震災における神戸ポートアイラ ンドNS 波および神戸海洋気象台 NS 波, 1968 年の十 勝沖地震における八戸NS 波, 1940 年のインペリアル ヴァレ一地震におけるエルセントロ観測地震 NS 波 (以下, 神戸 PI-NS 波, 神戸気像台 NS 波, 八戸NS 波, エルセントロ NS 波と略称する)を選定した.

\section{$5 \cdot 2$ 応答解析結果}

$5 \cdot 2 \cdot 1$ 固有振動数と振動モード 解析から得ら れた自立型クレーンの 1 次固有周期は, 非免震(Casel) の場合は $1.34 \mathrm{~s}$, 平行リンク型免震装置を設置した (Case2)場合は 4.07s であった. 図 7 に, 自立型クレー ンの振動モードを示す. 非免震の場合, マスト全体が 大きく曲げ振動しているが, マスト基部に平行リンク 型免震装置を設置することにより, 免震部分が変位し てマストの曲げ振動が大きく低減していることが分か る. 
建筑物の固有周期 $T_{b}$ を $0.5 \mathrm{~s}$ とした場合のステー支持 型クレーンの 1 次固有周期は, 非免震(Case3)の場合は 0.79s，ステー直上に平行リンク型免震装置を設置した 場合(Case4)は 3.90s, そして平行リンク型免震装置と免 震ステーを設置した場合(Case5)は 4.06s であった.

図 8 に，ステー支持型クレーンの 1 次振動モードを 示す．ステー支持型クレーンにおいては，非免震の場 合マストのステーより上部が大きく振動しているが, ステー直上に平行リンク型免震装置を設置した場合お よび平行リンク型免震装置と免震ステーを設置した場 合，マストの曲げ振動が大きく低減していることが分 かる.

紙幅の関係から結果は省略するが，建築物の固有周 期 $T_{b}$ を変化させても，Case4 およびCase4 では，マス 卜の曲げ振動が低減していることがわかった，すなわ ち，ステー支持型クレーンにおいては，ステー直上に 平行リンク型免震装置を設置することがマストの曲げ 振動を低减するのに有効である。

5.2.2 自立型クレーンの地震応答 図9に神戸 PI-NS 波に対する時刻歴応答解析結果を示す．図 9(a)
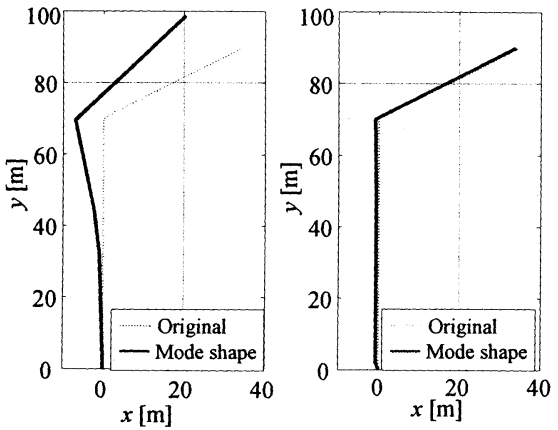

(a) Without isolator (Case1)

(b) With isolator (Case2)

Fig.7 Vibration modes of Self-stand type crane
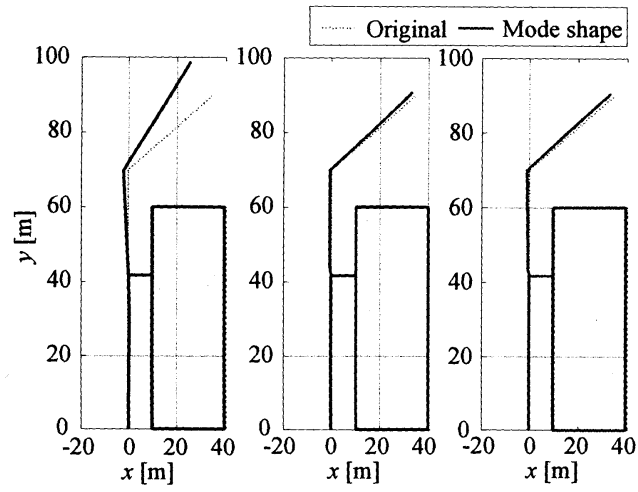

(a) Case3

(b) Case 4

(c) Case 5

Fig. 8 Vibration mode s of stay-support type crane $\quad\left(T_{b}=0.5 \mathrm{~s}\right)$
にマスト頂部に位置する旋回部の水平加速度 $\ddot{x}_{4} を,(b)$ に層せん断力係数 $C_{h}$ を, (c)に平行リンク型免震装置上 部受台の水平変位 $x_{l}$ を，(d)に入力として用いた神戸

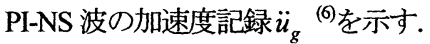

図から,クレーン旋回部の加速度 $\ddot{x}_{4}$, 層せん断力係 数 $C_{h}$ の最大値は共に, 免震装置を設置することにより 大幅に低减されていることがわかる，一方，平行リン ク型免震装置の水平変位 $x_{l}$ の最大値は $0.6 \mathrm{~m}$ と若干大 きな值なっている．詳細は省略するが，他の3つの地 震波に対するクレーン旋回部の加速度，層せん断力係 数、免震装置の水平変位共に, その最大值は神戸 PI-NS 波以下である.

なお，全ての地震波に対して，免震機構を取り付け ることにより, せん断力係数 $C_{h}$ の最大值が, 現行のク レーン構造規格》における震度 0.2 を下回る結果とな った.

$5 \cdot 2 \cdot 3$ ステ一支持型クレーンの地震応答 図 10 に, 建築物の固有周期 $T_{b}=2.0 \mathrm{~s}$ の場合の神戸 PI-NS

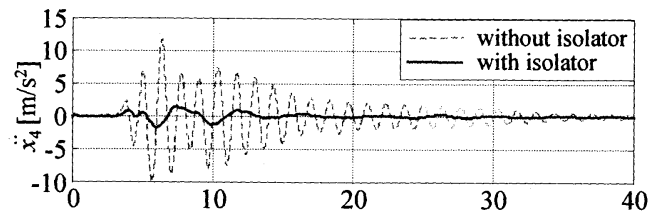

(a) Acceleration of slewing part

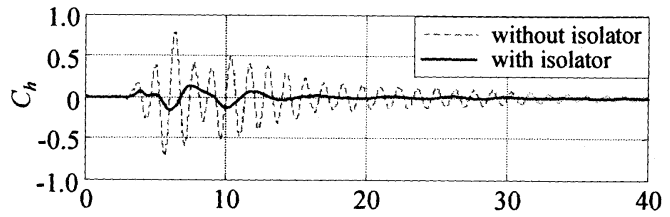

(b) Base shear coefficient

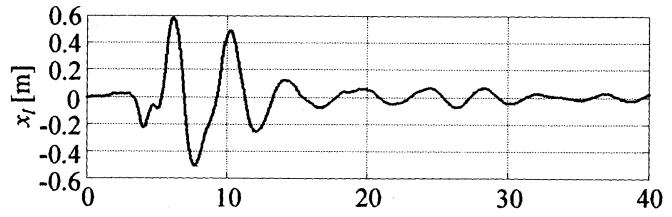

(c) Displacement of seismic isolator

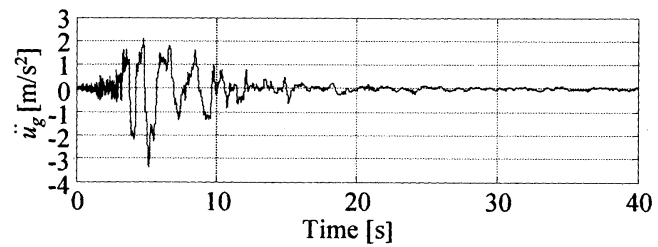

(d) Seismic acceleration of Kobe PI-NS

Fig.9 Seismic response of self-stand type crane 
波に対する時刻歴応答解析結果を示す. 図 10 (a)に建 築物の水平加速度 $\ddot{x}_{b}$ を, (b)に旋回部の水平加速度 $\ddot{x}_{4}$ を, (c)および(d)に層せん断係数 $C_{h u}$ および $C_{h}$ を，(e) に平行リンク型免震装置上部受台の水平変位 $x_{l}$ を, (f)

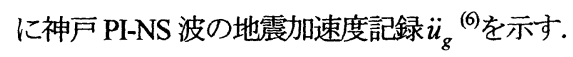

これらの結果から, 以下のことが分かる. 非免震ク レーンでは，マスト基部からの地震入力に加えて建築

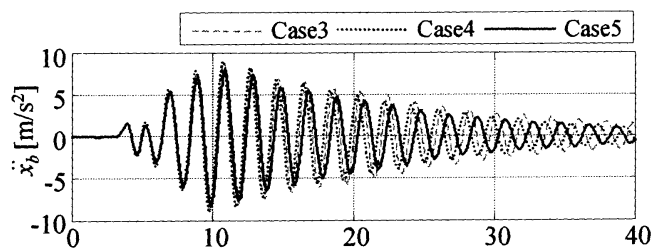

(a)Acceleration of building

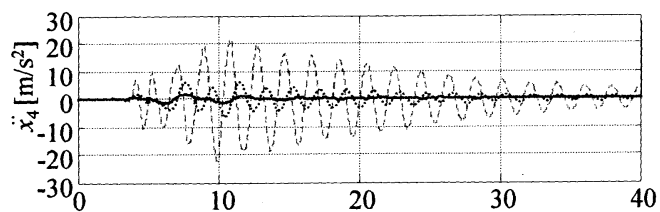

(b) Acceleration of slewing part

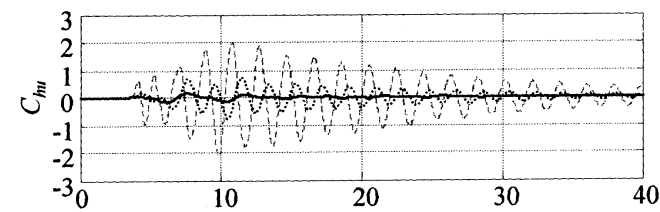

(c) Base shear coefficient of upper stay

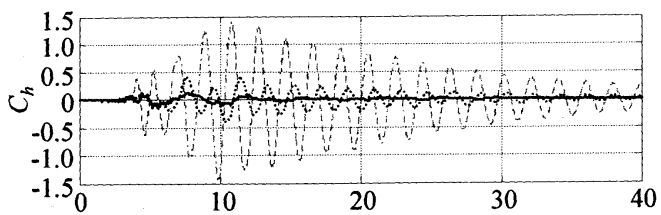

(d) Base shear coefficient of entire crane

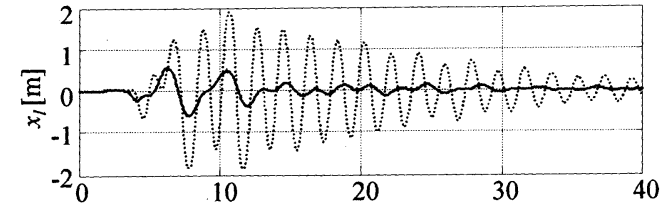

(e) Displacement of seismic isolator

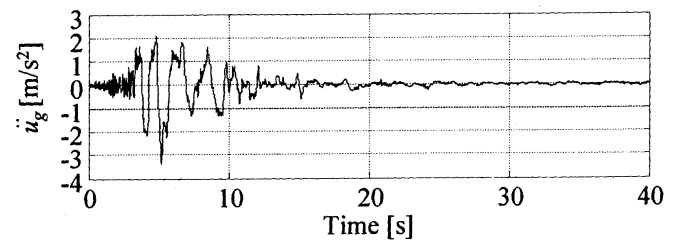

(f) Seismic acceleration of Kobe PI-NS

Fig.10 Seismic response of stay supported type crane
物からの入力があるために, 層せん断力が自立型クレ ーンよりかなり大きくなる. クレーン旋回部の最大加 速度は，平行リンク型免震装置を設置することにより 非免震時より小さくなるが，ステーを免震化すること によりさらに低減されている. 層せん断力係数 $C_{h u}$, $C_{h}$ および平行リンク型免震装置上部受台の水平変位 $x_{l}$ についても同様に低減する傾向が見られる. これは, Case4 と Case5 の振動モードが似ていても, Case4 の場 合はクレーン基礎部からの地震入力に加え，建築物か らの励振力によってマストが加振されるためにクレー ンの応答が充分小さくならないためである.すなわち, マストのみを免震するよりも，ステーも免震化するほ うが地震慣性力を低減する効果が大きいことが分かる.

なお，建築物の質量はクレーンの質量の約 100 倍あ るので, クレーンの免震装置の有無による建築物の応 答加速度への影響はほとんど見られない．

\section{6. 考 察}

図 11 に，ステー接続部より上部の層せん断力係数 $C_{m u}$ の最大値に対する建築物の固有周期の影響を示し た. 図中, 各地震波の応答スペクトルを重力加速度で 除したものをSpect.として参考に示した. これにより, 各地震波の卓越周期成分がわかる. 図 11 (a)は神戸 PI-NS 波, (b)は神戸気象台 NS 波, (c)は八戸NS 波, (d) はエルセントロ NS 波に対する結果をそれぞれ示して いる.

非免震, すなわち, Case3 における $C_{h u}$ の最大値は, 建築物の固有周期が $1 \mathrm{~s}$ 付近において大きくなってい

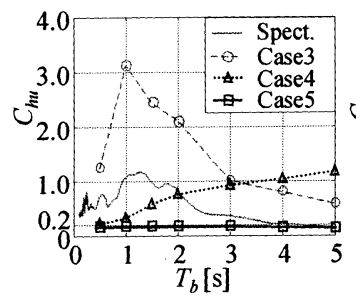

(a) Kobe PI-NS

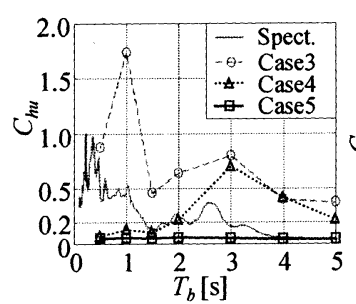

(c) Hachinohe-NS

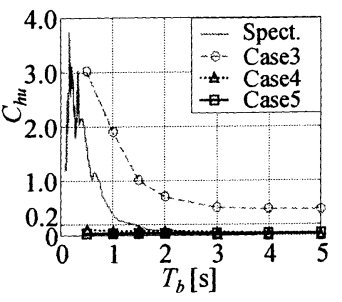

(b) Kobe MO-NS

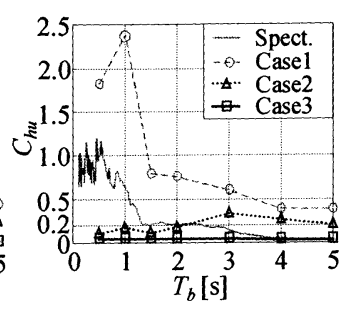

(d) El-Centro-NS

Fig.11 Effect of natural period of the building on $C_{h u}$ 
るが，これは非免震タワークレーンの固有周期と合致 したため, 増幅率が大きくなったことによる. マスト のみ免震した Case4 では，極めて短い周期成分が卓越 する神戸海洋気象台 NS 波以外は, 建築物の固有周期 と地震波の卓越周期が近い周期領域で $C_{h u}$ が大きくな っている. 一方, マストとステーを免震した Case5 で は, 建築物の固有周期に関称ず $C_{l m}$ の最大值は常に 0.2 以下になっている. このことは, ステーを免震化す ることにより，建築物からの励振を絶縁する効果が大 きいことを示している. すなわち, マストのみならず ステーも免震化することがステー支持型クレーンの免 震機構として有効であることがわかる.

やや長周期成分が卓越する神戸 PI-NS 波に対する平 行リンク型免震装置の応答変位が大きくなったが, 免 震装置の減衰係数を大きくすることにより低减できる と考えられる. 図 12 に, 减衰係数加求まるタワーク

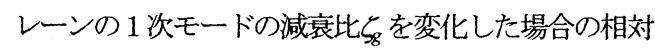
変位 $x_{l}$ と層せん断力係数 $C_{h}$ の関係を示す.

図加ら, 減衰比 $\zeta_{g}$ を増加すると共に, $x_{l}$ は減少し $C_{h}$ は増加する傾向が分かる. ら を 0.3 程度まで増加した 場合, 層せん断力の増加は僅かであるが, 相対変位は 25-30\%程度小さくなっている. לgは平行リンク型免震 装置のダンパーにより調整できるので, 設計上許容で きる層せん断力と相対変位の兼社合いで決めることが できる. また，相対変位が大きくなる場合には，スト ッパーにより変位を拘束することも可能である.

タワークレーンの作業中ジブの姿勢角は常に変化す るが，非免震の場合の姿勢角変動に伴う固有周期変化 は, 高々 10\%程度である. 従って, 免震化して, 固有 周期を長周期化すれば, 姿勢角変動による 1 次固有周 期への影響はほとんど無くなる.

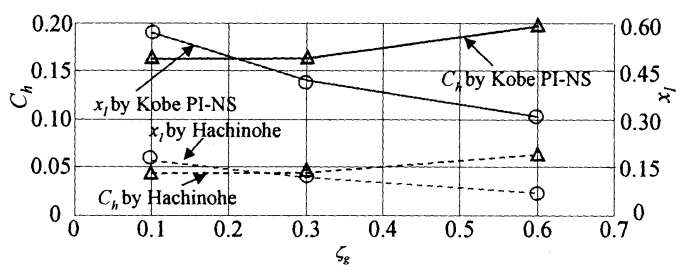

Fig.12 Effect of damping ratio on $x_{l}$ and $C_{h}$

\section{7. 結言}

(1) 立体的な平行リンク機構を用いた水平 2 次元免震 装置と軸剛性を可変にした免震ステーで構成される タワークレーンに代表される塔状構造物用の免震機 構を提案した.

(2) 平行リンク型免震装置の模型実験から, 免震装置 として動作することを確認した.

(3) 自立型クレーンに平行リンク型免震装置を設置す ることにより，クレーンマストおよび旋回体の応答 加速度を大幅に低減することが可能であることを地 震応答解析により示した.

(4) ステー支持型クレーンは，ステーを介しての建築 物からの入力が大きいので, ステーも免震する必要 がある.

(5) ステー支持型クレーンに平行リンク型免震装置と 免震ステーを設置することにより, 自立型クレーン の場合と同様に, クレーンマストおよび旋回体の応 答加速度を大幅に低减することが可能であることを 地震応答解析により示した.

\section{文献}

(1) The committee for earthquake resistant investigation of crane, The report on the affection of Hanshin Awaji Earthquake for crane structure, The Japan Crane Association, (1996), pp.1-66 (in Japanese)

(2) The special investigation committee on Great Hanshin Awaji Earthquake damage, The Machines and Industrial Equipments Damage due to the Southern Hyogo prefecture Earthquake, JSME, Maruzen, (1996), pp.161-162 (in Japanese)

(3) Editorial Committee, Falling accident due to the earthquake and its countermeasure for tower crane, Journal of the Japan Crane Association, Vol.40, No.11, (2002), pp.41-45 (in Japanese).

(4) Miyamori, K., Matsunaga, S. and Tohdo, M., Dynamic behavior during earthquake and countermeasures of tower crane under construction of high-rise building, Proceedings of Architectural Institute of Japan, (2004), pp.667- 668 (in Japanese).

(5) Takanashi S., A study on the seismic resistance of tower crane for construction use, Crane, Vol.1, No.1 (2003) pp.14-30 (in Japanese).

(6) K-net http://www.k-net.bosai.go.jp/k-net/

(7) Ministry of Health, Labour and Welfare, Standard for Crane Structure, Japan Crane Association, (2002), p.27 (in Japanese). 